\title{
Svensk yrkeslärarutbildning efter reformen 2011: Lärarstudenters uppfattningar om antagning, VFU och läraranställning
}

\author{
(Swedish vocational teacher education after the reform 2011: \\ Teacher students' perceptions of admission, \\ practicum internship and teacher appointment)
}

\author{
Hamid Asghari ${ }^{1} \&$ Ingrid Berglund ${ }^{2}$ \\ ${ }^{1}$ Karlstads universitet, Sverige (hamid.asghari@kau.se) \\ ${ }^{2}$ Göteborgs universitet, Sverige
}

\begin{abstract}
Through a survey to former vocational teacher students at two universities in Sweden, we explore their perceptions of admission, practicum internship during vocational teacher education, and employment as a vocational teacher after education, since teacher education reform in 2011.

The questionnaire used in the survey was answered by 140 former teacher students and the result contributes with knowledge about which vocational subjects were applied for, and which subjects the students later were admitted to, how long the former students' professional experience was when they applied for the education. The result shows that measures should be taken to support the application process. The study also illustrates how students perceive their practicum at schools and to what extent they were taught in their vocational subjects, and how they value the supervision during the practicum at schools. Here, we can draw conclusions from the questionnaire about differences between different vocational programmes regarding the supervision. Finally, we examined what happened after the vocational teacher education and we see that a large majority of former students have employment as vocational teachers, but that the possibilities of competence development and the broadening of the competencies for more vocational subjects vary.
\end{abstract}

Keywords: vocational teacher education, vocational teacher students, application for vocational teacher education, practicum internships, supervisor at work placements at schools

NJVET, Vol. 10, No. 2, 21-43 Magazine article doi: 10.3384/njvet.2242-458X.2010221

Hosted by Linköping University Electronic Press C The authors 


\section{Inledning}

Genom en enkät som belyser studenternas antagning, VFU (verksamhetsförlagd utbildning) under yrkeslärarutbildningen samt anställning som yrkeslärare efter sin lärarutbildning utforskar vi tidigare yrkeslärarstudenters uppfattningar om sin lärarutbildning efter lärarutbildningsreformen 2011 vid två svenska lärosäten. Lärarutbildningsreformen 2011 innebar förändringar av yrkeslärarutbildningen som främst motiverades av den stora bristen på behöriga yrkeslärare och att stora pensionsavgångar bland yrkeslärare var förestående. En åtgärd för att få fler sökande var att förkorta yrkeslärarutbildningen från 180 till 90 högskolepoäng (motsvarande 3 resp. 1,5 års heltidsstudier). Förändringen motiverades av att tidigare reformer hade resulterat $i$ en avsevärd förlängning av yrkeslärarutbildningen vilket ansågs leda till färre sökande (Regeringens proposition, 2010). Även antagningen till yrkeslärarutbildningen förändrades radikalt. Före reformen kunde yrkeslärare bli behöriga att undervisa i alla yrkesämnen som ingick i ett yrkesprogram. Efter reformen sker antagningen till yrkeslärarutbildningen till de yrkesämnen som finns i de gymnasiala yrkesprogrammen. Motivet som framfördes var att yrkeskunnande förändras över tid och att antagning till yrkesämnen skulle kunna bidra till ökad flexibilitet och möjlighet till kompetensutveckling för lärarna inom yrkesämnen (SOU 2008:112).

Antagningen sker utifrån särskilda behörighetskrav på kvalificerade och relevanta yrkeskunskaper (UHR, 2017) som kan grundas i såväl arbetslivserfarenheter som gymnasieskolans kurser och eftergymnasial utbildning exempelvis yrkeshögskola eller specialiserade kurser som privata utbildningsanordnare tillhandahåller. De särskilda behörighetskraven definieras genom kvalificerade och relevanta yrkeskunskaper och kan revideras och aktualiseras över tid (UHRFS 2013:4; UHRFS 2017:3; UHRFS 2018:3).

Inför antagningen till yrkeslärarutbildningen valideras de sökandes kvalificerade och relevanta yrkeskunskaper för yrkesämnen som den sökande avser att få behörighet att undervisa i (UHRFS 2013:4). Ett system för validering av yrkeskunskaper infördes parallellt med reformen 2011. För att bedömningarna av de sökandes yrkeskunskaper i ett yrkesämne ska bli likvärdiga uttrycks dessa krav i form av kunskapskriterier. För närvarande kan studenter antas till 211 yrkesämnen i 20 gymnasiala yrkesprogram, inom ungdomsgymnasiet, gymnasiesärskolan och vuxenutbildningen.

Hela yrkeslärarutbildningen bygger efter reformen på den så kallade utbildningsvetenskapliga kärnan (UVK) som motsvarar 60 högskolepoäng (hp) av fastställda kurser gällande centrala och generella kunskaper för alla lärarutbildningar, och ytterligare $30 \mathrm{hp}$ som VFU som genomförs på skolor med gymnasial yrkesutbildning. Både UVK och VFU bör enligt regeringens proposition "vara nära knuten till det aktuella yrkesämnet" (Regeringens proposition, 2010, s. 30). 
Som universitetslärare i yrkeslärarutbildningen har vi egna erfarenheter av reformen och vid flera tillfällen har vi hört spekulationer om vad reformeringen av yrkeslärarutbildningen har inneburit för studenterna gällande såväl antagningen som genomförandet av utbildningen, där VFU och handledningen i yrkesämnen framstått som särskilt kritiska områden. Exempelvis handlar det om att de studenter som genomför sin lärarutbildning i egen tjänst riskerar att inte få kvalificerad yrkesämnesdidaktisk handledning. Vidare har vi hört att examinerade studenter får tjänster utifrån program, snarare än utifrån specifika yrkesämnen, då skolorna inte kan erbjuda heltidstjänster inom de specifika yrkesämnen som läraren har fått behörighet för. Denna typ av hörsägner har varit en drivkraft för vårt intresse av att undersöka yrkeslärarstudenters uppfattningar om antagningen till yrkeslärarutbildningen, VFU under utbildningen samt anställning som yrkeslärare efter utbildningen. Föreliggande studie är begränsad till två lärosäten där vi själva är verksamma: Karlstads universitet och Göteborgs universitet.

\section{Den svenska yrkeslärarutbildningens förändring över tid}

Lärarutbildningsreformen 2011 och dess konsekvenser för yrkeslärarutbildningen kan sättas i ett historiskt perspektiv av den svenska yrkeslärarutbildningens förändring över tid.

På 1950- och 1960-talen expanderade yrkesutbildningen kraftigt i Sverige och det stora behovet av yrkeslärare innebar att staten ökade statsanslagen för yrkeslärarutbildning (Berglund, 2009; SOU 1994:101). 1967 startades det självständiga Yrkespedagogiska institutet (YPI) med en yrkespedagogisk och arbetslivsinriktad verksamhet (Hedman, 2001; Thång, 2013). Vid YPI utbildades både yrkeslärare för gymnasieskolan och instruktörer inom arbetsmarknadsutbildningen (Thång, 2013). Kraven på formell utbildning för yrkeslärare i gymnasieskolan ökade vid införlivandet av yrkesutbildningen inom gymnasieskolans organisation enligt 1970 års läroplan, och 1977 års högskolereform medförde att de formella kraven på yrkeslärarutbildningen höjdes ytterligare (Thång, 2013).

Många branscher ansåg att kompetensnivån hos yrkeslärarna var generellt för låg och att yrkeslärarna framförallt saknade kunskaper i svenska, engelska och matematik. Som en konsekvens av arbetslivets förändrade kompetensbehov och gymnasieskolans utveckling genomfördes därför en utredning av lärarutbildningen (SOU 1994:101). Utredningen visade att det behövdes en förstärkning av både allmän och specifik kompetens för gymnasielärare i yrkesämnen. Den allmänna kompetensen handlade om förmåga att organisera undervisningen, motivera eleverna att söka kunskap för att nå bestämda mål och att kunna utvärdera uppnådda resultat. Behovet av specifik kompetens utgick från olika yrkesbranschers kompetensbehov. Exempelvis skulle VVS-lärare bredda sin kompetens med ett ökat inslag av systemkunskap och funktionsförståelse men också slå 
vakt om hantverkskunnandet. Bygg- och anläggningslärare behövde både bredare och djupare kompetenser för olika produktions- och verksamhetsområden. För frisörlärare handlade det mer om att få en internationell kompetens genom bland annat förstärkt språkundervisning och samhällskunskap i ett Europaperspektiv (SOU 1994:101). Mot dessa behov föreslog utredningen en utökning av yrkeslärarutbildningen till motsvarande $180 \mathrm{hp}$ varav praktiska och pedagogiska studier utgjorde motsvarande $90 \mathrm{hp}$ och därtill fanns krav på högskoleutbildning inom relevant yrkesområde motsvarande $90 \mathrm{hp} \mathrm{(SOU} \mathrm{1994:101).} \mathrm{Behovet} \mathrm{av} \mathrm{en}$ ny och längre yrkeslärarutbildning var också kopplad till den förändring av lärarrollen som skedde under 1990-talet, då mål- och resultatstyrning infördes som en styrningsprincip i det svenska skolsystemet (SOU 2008:112). Den lärarutbildningsreform som genomfördes 2001 innebar att yrkeslärarutbildningens omfattning för att få lärarexamen med yrkeslärarinriktning hade ökats från motsvarande 60 hp till 180 hp från 1995 till 2001 (SOU 2008:112, s. 46).

Kravet på motsvarande $90 \mathrm{hp}$ högskoleutbildning inom relevant yrkesområde medförde att antalet sökande till yrkeslärarutbildningen minskade och det antogs innebära att bristen på yrkeslärare med pedagogisk högskoleexamen skulle öka ytterligare (SOU 2008:112). För att öka andelen yrkeslärare med pedagogisk högskoleexamen (lärarexamen) gjorde staten därför en satsning på en Särskild lärarutbildning (SÄL III) mellan åren 2005 och 2009. SÄL III-utbildningen riktade sig både till redan verksamma yrkeslärare som saknade lärarexamen och till nyrekryterad lärarpersonal (Högskoleverket, 2011a). Den satsningen bedömdes som lyckad och följdes av projektet Vidareutbildning av lärare (VAL) som riktar sig till de som är verksamma i läraryrket och som saknar maximalt $30 \mathrm{hp}$ inom den utbildningsvetenskapliga kärnan för att få en lärarexamen. VAL riktar sig även till yrkeslärare och ges på ett fåtal lärosäten, däribland Karlstads universitet.

Inför lärarutbildningsreformen 2011 gjordes en utredning med uppdraget att rekrytera fler yrkeslärare (SOU 2008:12). Utredningen kom fram till att det tidigare kravet på en relevant högskoleutbildning om $90 \mathrm{hp}$ eller motsvarande utbildning inom yrkesområdet var ett hinder för att få fler sökande till lärarutbildningen och utredningen rekommenderade att yrkeslärarutbildningen förkortades från $180 \mathrm{hp}$ till $90 \mathrm{hp}$. Att förkorta yrkeslärarutbildningen samt att ändra på antagningen ansågs kunna förbättra andelen behöriga yrkeslärare. Siffror som lyftes fram i utredningen var att en så låg andel som $43-49 \%$ av lärarna saknade pedagogisk högskoleexamen (SOU 2008:112, s. 27).

Lärarutbildningsreformen som sjösattes hösten 2011 omfattade fyra olika examina varav yrkeslärarexamen är en ${ }^{1}$ (Regeringens proposition, 2010). Reformen och den förkortade utbildningen innebär att yrkeslärarstudenterna inte får en akademisk examen, vilket kräver minst $180 \mathrm{hp}$. Detta begränsar yrkeslärares möjligheter att gå vidare i fortsatta studier i det akademiska utbildningssystemet (SOU 2008:112). 


\section{Stort behov av yrkeslärare}

I Sverige är det sedan lång tid en stor brist på utbildade yrkeslärare inom flertalet yrkesprogram (Högskoleverket, 2009; Skolverket, 2018). Arbetslösheten bland behöriga yrkeslärare har länge varit låg och den svenska arbetsmarknaden förutsägs vara god för yrkeslärare (Saco, 2019). Bristen på yrkeslärare var också som framgått ett tungt vägande argument för reformeringen och förkortningen av utbildningen för yrkeslärare i reformen 2011 (SOU 2008:12). Andelen yrkes-lärare med pedagogisk högskoleexamen varierar dock starkt mellan yrkesprogrammen. Enligt statistik från Skolverket för läsåret 2017/18 hade Barn- och fritidsprogrammet den högsta andelen lärare med pedagogisk högskoleexamen $(86,1$ $\%)$, därefter kommer följande yrkesprogram: Restaurang och livsmedel (73,3 \%), Vård och omsorg $(69,2 \%)$, Handel och administration $(67,5 \%)$, Hotell och turism $(63,4 \%)$, Hantverk (62,9\%), El och energi (51,7 \%), Bygg och anläggning $(50,4 \%)$, Industriteknik (48,5\%), Naturbruk $(47,7 \%)$, Fordon och transport (47\%) samt VVS och fastighet (38,7\%) (Skolverket, 2018).

\section{Yrkeslärarutbildningen efter reformen 2011}

Yrkeslärarstudenter har redan utbildat sig till ett yrke och varit verksamma som yrkesutövare innan de utbildar sig vidare till yrkeslärare. Befintliga yrkeskunskaper är således en förutsättning för att bli yrkeslärare. Med det menar vi att yrkeslärarutbildningen kan betraktas både som en vidareutbildning inom yrkesområdet och som en utbildning till ett nytt yrke som lärare (Köpsén, 2014).

Yrkeslärarutbildningen i Sverige består som framgått av $90 \mathrm{hp}$, varav $60 \mathrm{hp}$ ligger inom den utbildningsvetenskapliga kärnan (UVK) och $30 \mathrm{hp}$ utgörs av VFU (se t.ex. All, Pettersson \& Teräs, 2018). Yrkeslärarutbildningen genomförs på varierande sätt vid olika lärosäten; både som heltidsstudier och deltidsstudier, som distansutbildning med campusförlagda delar och vanligtvis som en kombination av dessa delar. Arbetssätten varieras med föreläsningar, individuellt arbete, redovisningar, gruppdiskussioner och examinerande seminarier (se t.ex. Andersén, Asghari \& Petersson, 2018; Annerberg \& Fändrik, 2019). VFU genomförs i skolor med gymnasial yrkesutbildning, vilket förekommer i såväl ungdomsgymnasiet som vuxenutbildning och särskola. VFU examineras av lärosätenas personal i förhållande till ett innehåll som är styrt av lärandemål i kursplaner. Det behövs därför ett samspel mellan VFU-aktiviteter och campusförlagda aktiviteter i yrkeslärarutbildningarna för att studenterna ska utveckla relevanta yrkesämnesdidaktiska kunskaper (Annerberg \& Fändrik, 2019).

\section{Ansökan och antagning}

I samband med antagningen till yrkeslärarutbildning sker som framgått en validering av sökandens yrkeskunskaper i relation till specificerade yrkesämnen. Johansson (2019) problematiserar möjligheter att bedöma yrkeskunnande i termer 
av yrkesämneskunskaper. De sökandes yrkeskunskap valideras inför antagningen, men kriterierna är generella och inte anpassade till ämnen i olika yrken. Johansson (2019) uppmärksammar också att det sker transformering och anpassning av yrkeskunskaperna för att de ska passa utbildningssystemet. Valideringen görs bland annat utifrån sökandes skriftliga berättelser om yrkeserfarenheter och yrkeskunskaper. Förutom skriftliga berättelser om yrkeserfarenheter och yrkeskunskaper ska de sökande kunna bestyrka sina kunskaper genom exempelvis arbetsintyg, tjänstgöringsintyg, intyg från branschorganisationer samt yrkesexamina från lärlingsutbildningar, gymnasieutbildningar och högskolor (se t.ex. Berglund, Höjlund, Kristmansson \& Paul, 2017; Isacsson, Stigmar \& Amhag, 2018; Samuelsson \& Johansson, 2018). Johansson (2019) uppmärksammar dessutom att kunskapsbeskrivningar som är vanliga i ett akademiskt sammanhang inte är något som en yrkesutövare gör i sin vardagliga verksamhet. Det framstår därför som komplext för sökande att formulera sina yrkeskunskaper och sitt yrkeskunnande i termer av yrkesämnen. Yrkeskunnande inom olika yrken har också olika karaktär och är inte så lätta att formulera enligt de riktlinjer som anges i ansökan (Johansson, 2019). Sökande bär också på avancerade yrkeskunskaper där delar av kunskaperna är tysta och inte kan skrivas fram i ansökan. Det finns därför en risk att den sökandes skriftliga förmåga valideras för antagning och inte dennes yrkeskunskaper (Johansson, 2019).

Andersson och Fejes (2014) lyfter också fram maktperspektivet i validering i förhållande till valideringens utformning och genomförande. Bedömningen av om de sökande har kvalificerade och relevanta yrkeskunskaper kan ske på olika sätt på olika lärosäten, exempelvis genom valideringsprogram eller autonomt på universiteten. Några lärosäten genomför även intervjuer med de sökande till yrkeslärarprogrammen.

De särskilda behörighetskraven (som också benämns som specialiserade kunskaper) har sin grund i det svenska kvalifikationsramverket SeQF, ett nationellt kvalifikationsramverk för specialiserade kunskaper (Regeringskansliet, 2014). Med specialiserade kunskaper menas erfarenhetsbaserade och formell utbildning inom yrket (Högskoleverket, 2011b). För att de sökandes yrkeskunskaper i ett yrkesämne ska bedömas likvärdigt finns det särskilda kunskapskriterier (UHR, 2017). Likvärdigheten i bedömningarna ifrågasätts dock i flera studier, där exempelvis yrkesbranscherna betonar vikten av det tysta yrkeskunnandet (Johansson, 2019; Panican, 2016).

Efter genomförd yrkeslärarutbildning får studenterna behörighet att undervisa i de ämnen de har blivit antagna till, med möjligheten att bredda sina ämnesbehörigheter efter avslutad yrkeslärarutbildning. Vilka yrkesämnen som studenten har blivit antagen till kan även vara avgörande för det sätt på vilket studenten formas in i skolmiljön, då yrkeslärarstudenter som framgått kan bli antagna till ett eller flera ämnen som kan finnas i flera olika yrkesprogram (UHR, 2017). 
Många sökande till yrkeslärarutbildningen arbetar redan som obehöriga yrkeslärare innan de ansöker om utbildningen (Isacsson m.fl., 2018) och kan ha gedigna erfarenheter av yrkesundervisning. Det som de saknar är då själva dokumentationen över didaktiska kunskaper och kompetens (All m.fl., 2018; Andersén m.fl., 2018).

\section{Verksamhetsförlagd utbildning (VFU)}

Under VFU ska studenterna utveckla sin lärarprofession utifrån lärandemål där handledare på VFU-skolorna fungerar som stöd för att studenterna ska kunna uppnå lärandemålen. Handledarnas uppgift är att skapa förutsättningar för utveckling av studenternas lärarprofession samt att kunna bedöma var i professionsutvecklingen studenterna befinner sig (se t.ex. Håkansson, 2017). VFU anses även vara viktigt för att studenterna ska få möjlighet att utveckla sin undervisningsskicklighet i relation till forsknings- och erfarenhetsbaserad kunskap (se t.ex. Andersén m.fl., 2018). VFU kan även ses som lärarstudentens väg till arbete. Brennan Kemmis och Green (2013) framhåller att VFU också har en viktig roll för att arbetslivet (i vårt fall, skolan där yrkeslärarstudenten gör sin VFU) ska kunna bedöma studentens undervisningsförmåga och vad studenten behöver utveckla.

Studenternas utveckling av sina undervisningskunskaper kan exempelvis ske genom att de systematiskt reflekterar över sina erfarenheter under VFU i en så kallad självvärdering (jfr "own self-feedback" i Hattie \& Timperley, 2007, s. 86). VFU medverkar också till att yrkeslärarstudenter får erfarenheter av vad det innebär att vara lärare som i sin tur bidrar till att forma en ny yrkesidentitet som lärare (Hultman, Wedin \& Schoultz, 2012). Genom VFU kan studenters profession utvecklas, som exempelvis självständighet, social kompetens och förståelse av varierande förutsättningar i undervisningssituationer (se t.ex. Hultman m.fl., 2012).

I mötet med VFU-handledare och lärarkollegor lär sig studenten att planera och genomföra undervisning med utgångspunkt i styrdokumenten, samt att bedöma elevers kunskaper (jfr Du Plessis, Marais, Van Schalkwyk \& Weeks, 2010). Handledaren har i uppdrag att ge lärarstudenten handledning utifrån lärarutbildningens ramar och krav, men det finns också andra villkor som har betydelse för hur lärarstudenten blir delaktig i en skolas miljö och gemenskap. Det kan handla om fikastunderna på jobbet, relationen mellan VFU-handledaren och lärarstudenten samt formella och informella möten mellan lärarstudenten och skolpersonalen. Även VFU-handledarens syn på lärarutbildning och den process där lärarstudenten utbildas är avgörande för det sätt på vilket lärarstudenten blir delaktig i skolmiljön (Andersén \& Asghari, 2016; Hultman m.fl., 2012). VFU-skolorna ger varierande förutsättningar för hur studentens yrkesläraridentitet formas, exempelvis beroende av skolans och VFU-handledarens syn på lärare- och 
elevrelationer, ordning och reda i klassrummet samt ämnescentrerad undervisning men även av de av lärosätet givna uppgifter som lärarstudenten ska genomföra (se t.ex. Andersén \& Asghari, 2016).

Kompetensutveckling efter yrkeslärarexamen för breddning av yrkesämnesbehörighet Yrkeslärare behöver genom kontinuerlig kompetensutveckling säkerställa, upprätthålla och utveckla både sina yrkesämnes- och pedagogiska kunskaper, ett uppdrag som förefaller mer komplext än för andra lärargrupper (Andersson \& Köpsén, 2014). I en svensk enkätstudie med fokus på yrkeslärares kontinuerliga kompetensutveckling har yrkeslärares deltagande i olika kunskapsutvecklande aktiviteter och yrkesundervisning studerats (Andersson \& Köpsén, 2018). Studien visar bland annat att det gränsöverskridande arbetet med att skapa sammanhang och organisera för helheten i utbildningen mellan skola och arbetsliv utifrån lokala och geografiska omständigheterna kan påverka aktivitetsformer för yrkeslärare som exempelvis utbildning inom den forna yrkesbranschen och läsning av yrkesrelaterade texter (Andersson \& Köpsén, 2018).

Yrkeslärarna rör sig mellan olika gemenskaper i skola och arbetsliv och mellan sina yrkesidentiteter som yrkesperson och som lärare (Fenton-O'Creevy, Brigham, Jones \& Smith, 2015; Köpsén, 2014). Yrkeslärarnas kontinuerliga deltagande i kompetensutveckling berörs således av gränsöverskridande arbetsuppgifter mellan skola och arbetsliv (Andersson \& Köpsén, 2018). Yrkeslärares kompetensutveckling kan också ske $\mathrm{i}$ arbetslivet och då främst $\mathrm{i}$ förhållande till yrkesbranschers behov av förnyad yrkeskompetens (se t.ex. Fenton-O'Creevy m.fl, 2015). En kontinuerlig kontakt med arbetslivet kan därför skapa lämpliga förutsättningar för yrkeslärare att få uppdaterad kunskap om teknikutvecklingen inom sitt yrkesområde.

Internationella studier visar att kompetensutveckling för yrkeslärare har flera positiva effekter för yrkeslärares undervisning gällande ämnes- och pedagogiska kunskaper samt förmågan att reflektera och förbättra sin praxis (Lloyd \& Payne, 2012). Enligt Lloyd och Payne (2012) kan yrkeslärares kompetensutveckling relateras till deras arbetsuppgifter och till de möjligheter som ges för dem att delta i kompetensutveckling. En av de begränsningar som diskuteras av Andersson och Köpsén (2018) gäller yrkeslärarnas heltidsanställning eller deltidsanställningar, där yrkeslärare som arbetar deltid som lärare och deltid som yrkesutövare har större möjlighet till kompetensutveckling inom sitt yrke genom yrkesutövandet.

\section{Syfte och frågeställningar}

Studien syftar till att utforska hur tidigare yrkeslärarstudenter uppfattar sin yrkeslärarutbildning gällande antagningen, VFU samt sin anställning som yrkeslärare i yrkesämnen efter utbildningen. Utifrån syftet organiserades studiens frågeställningar i tre temata som också blev utgångspunkt för enkätundersökningen. 
Ansökan och antagning till yrkeslärarutbildningen

Vilka tidigare yrkeserfarenheter hade de tidigare studenterna inom de ämnen de sökte och antogs till?

Verksamhetsförlagd utbildning (VFU)

Hur genomfördes handledningen inom VFU i relation till studenternas yrkesämnen?

Efter avslutad yrkeslärarutbildning

Vad hände efter lärarutbildningen gällande anställning och möjlighet till kompetensutveckling?

\section{Metod och genomförande}

Vi valde att genomföra en webbaserad enkätstudie via Karlstads universitets webbaserade enkätverktyg. Enkäten pågick mellan 8 februari och 30 september 2018.

Enkätens frågor formulerades utifrån den kunskap vi skaffade oss om antagningen av yrkeslärarstudenter samt yrkeslärarutbildningens form och innehåll. Vi fick även konstruktiva synpunkter på enkätfrågorna från kolleger vid våra respektive lärosäten.

I de enkätfrågor där respondenterna skulle ange val av något eller några yrkesämnen har vi använt oss av Universitets- och högskolerådets (UHR) lista över kvalificerade och relevanta yrkeskunskaper för de 211 yrkesämnen som fanns när enkäten genomfördes (UHR, 2017). Dessa ämnen organiserades i sin tur efter de gymnasiala yrkesprogrammens yrkesämnen för att få en bättre överskådlighet.

Enkäten distribuerades via ett informationsbrev till alla tidigare yrkeslärarstudenter som påbörjade utbildningen efter lärarutbildningsreformen 2011 vid våra respektive lärosäten, Karlstads universitet och Göteborgs universitet.

Möjligheten att nå så många av dessa studenter som möjligt försvårades av att lärosätena varken hade aktuella e-postadresser eller uppdaterade hemadresser till studenter som lämnat utbildningen för mer än ett år sedan. Till dessa tidigare studenter använde vi postala utskick, med ett informationsbrev som innehöll en länk till enkäten, till de adresser som lärosätena hade tillgängliga. Det medförde med stor sannolikhet att svarsfrekvensen blev låg, särskilt bland de studenter som gick sin yrkeslärarutbildning närmast efter reformens genomförande. Vid Karlstads universitet skickades sammanlagt 394 enkäter till tidigare studenters hemadresser och e-postadresser och vid Göteborgs universitet skickades 244 enkäter till tidigare yrkeslärarstudenters hemadresser och e-postadresser som fanns tillgängliga. Totalt skickades således 638 informationsbrev till tidigare lärarstudenter vid de båda lärosätena. Postadresserna kan ha varit inaktuella och 
för att svara på enkäten var studenterna tvungna att använda en webbadress som fanns angiven i informationsbrevet. Det är också ovisst om studenter läser sin epost efter utbildningens avslut. Trots dessa omfattande problem med distributionen av enkäten svarade 140 tidigare yrkeslärarstudenter. Eftersom vi inte vet i vilken utsträckning länken till enkäten har nått fram till lärarstudenterna så kan vi inte ange någon relevant svarsfrekvens på enkäten. Vi är medvetna om att bortfallet har betydelse för en korrekt tolkning av enkäten statistiskt (Trost, 2012). En konsekvens är att inte alla yrkesämnen kan täckas på grund av de många möjliga yrkesämnena inom yrkeslärarutbildningen i förhållande till det relativt låga antalet respondenter. Vi har därför gjort programvisa sammanslagningar i resultatpresentationen. En studie i större skala skulle krävas för att kunna ge mer kunskap om utfallet på yrkesämnesnivå.

\section{Resultat}

140 tidigare yrkeslärarstudenter har deltagit i enkäten, men antalet svar på enskilda frågor varierar mellan 125 och 140. Åldersmässigt var gruppen 50-55 år störst (30\%), och $48 \%$ var män, $49 \%$ kvinnor och $3 \%$ ville inte definiera sitt kön.

Utifrån det stora antalet yrkesämnen i förhållande till antalet respondenter kan vi inte få detaljerad kunskap om varje yrkesämne. Därför har vi valt att beskriva resultatet utifrån de gymnasiala yrkesprogrammen som är totalt 20 . Eftersom inga respondenter i studien hade ansökt till yrkesämnen inom Sjöfartsutbildningen, Tågteknikutbildningen, Yrkesdansarutbildningen, Marinteknikutbildningen eller Utbildningen för samiska näringar så har dessa yrkesprogram tagits bort i resultatpresentationen. Även resultat med låg svarsfrekvens har tagits bort. Exempelvis när det gäller frågan om kombinationen av lärartjänst och annan tjänst har vi inte tagit med Teknikprogrammet - fjärde året i vår beräkning, eftersom det enbart var en respondent som svarade på frågan. Resultatet presenterats utifrån de tre temata och studiens frågeställningar.

\section{Ansökan och antagning till yrkeslärarutbildningen}

125 tidigare studenter svarade på frågan om hur de fick information inför sin ansökan till yrkeslärarutbildningen. 110 respondenter $(88 \%)$ svarade att de sökte information inför sin ansökan till yrkeslärarutbildningen på egen hand medan endast 15 respondenter (12\%) angav att de fick informationen genom vägledare.

140 respondenter hade ansökt för sammanlagt 168 yrkesämnen inom 15 yrkesprogram. 28 av dem (20 \%) ansökte om behörighet för yrkesämnen inom mer än ett program. Den högsta andelen studenter som blev antagna fanns för yrkesämnen inom Fordons- och transportprogrammet, Hantverksprogrammet, Bygg- och anläggningsprogrammet, Barn- och fritidsprogrammet, Vård- och omsorgsprogrammet och Handels- och administrationsprogrammet. Lägst antal studenter 
blev antagna för yrkesämnen inom Teknikprogrammet - fjärde året och Flygteknikutbildningen. De 140 respondenterna blev antagna till totalt 157 yrkesämnen inom 15 av yrkesprogrammen.

\section{VFU (Verksamhetsförlagd utbildning)}

På frågan om de tidigare studenterna under sin VFU enbart undervisade i de yrkesämnen de blev antagna till svarade 125 respondenter. Av de 125 respondenter svarade 94 (75 \%) att de enbart undervisade i de yrkesämnen de hade blivit antagna till. 31 respondenter (25\%) svarade att de även undervisade i andra yrkesämnen som de inte hade blivit antagna till. Det framkommer att studenter undervisade i sammanlagt 83 yrkesämnen som inte hade blivit antagna i.

På frågan om de tidigare studenterna under sin VFU hade haft en handledare med yrkesämneskunskaper i de specifika yrkesämnen som de själva var antagna till, svarade 126 respondenter. 99 av dem (79 \%) uppgav att de hade haft en VFUhandledare med specifika yrkesämneskunskaper i de yrkesämnen som de var antagna till. Av de 27 respondenter (21\%) som hade angett att de inte hade en VFU-handledare med specifika yrkesämneskunskaper i de yrkesämnen som de själva var antagna till, har 18 respondenter angett att de hade VFU i egen tjänst och inte hade några kollegor med behörigheter för de yrkesämnena.

Bristen på VFU-handledare med rätt yrkesämneskunskaper fanns inom sammanlagt 78 yrkesämnen.

Frågan om VFU-handledares betydelse för studenters nuvarande skicklighet som yrkeslärare besvarades av 123 respondenter, och det finns totalt 142 svar på frågan. Skillnaden beror på att studenterna som har varit antagna till flera yrkesämnen inom ett eller flera program har kunnat ge flera svar och ange att deras VFU-handledare ha haft mer betydelse för dem i ett yrkesämne inom ett program, och mindre betydelse i ett annat yrkesämne inom ett annat program. Av de 142 svaren anger 67 (47 \%) att VFU-handledare hade mycket stor eller ganska stor betydelse för studenternas nuvarande skicklighet som yrkeslärare i ämnet. 75 svar (53 \%) visar att VFU-handledare hade liten eller ingen betydelse alls för studenternas nuvarande skicklighet som yrkeslärare. Majoriteten av de studenter som svarade att deras VFU-handledare hade mycket stor eller ganska stor betydelse för deras nuvarande skicklighet som yrkeslärare finns i fallande ordning på:

- Barn- och fritidsprogrammet.

- Vård- och omsorgsprogrammet.

- Restaurang- och livsmedelsprogrammet.

Av de studenter som svarade att deras VFU-handledare hade liten betydelse eller ingen betydelse alls finns majoriteten i fallande ordning inom: 
- Industritekniska programmet.

- VVS- och fastighetsprogrammet.

- Bygg- och anläggningsprogrammet.

- El- och energiprogrammet.

- Hotell- och turismprogrammet.

- Fordons- och transportprogrammet.

Frågan om studenterna fick den handledning de behövde under sin VFU besvarades av 126 respondenter, som sammanlagt har gett 145 svar. Studenter som har varit antagna till flera yrkesämnen inom ett eller flera program, har svarat att de har fått den handledning de behövde i vissa yrkesämnen, men inte nöjaktig handledning i andra yrkesämnen. 89 av de 145 svaren (61 \%) visar att respondenterna ansåg att de fått den handledning de behövde under sin VFU, medan 56 svar $(39 \%)$ visar att studenterna inte fick den handledning de behövde.

De studenter som angav att de fick tillräcklig handledning under sin VFU fanns i fallande ordning inom:

- Hotell- och turismprogrammet.

- Restaurang- och livsmedelsprogrammet.

- Naturbruksprogrammet.

- Barn- och fritidsprogrammet.

- Vård- och omsorgsprogrammet.

- El- och energiprogrammet.

- Handels- och administrationsprogrammet.

Studenter på Hotell- och turismprogrammet samt studenter på El- och energiprogrammet hade tidigare svarat att deras VFU-handledare hade liten betydelse eller ingen betydelse alls för dem under deras VFU. Därför framstår svaret att de fick tillräcklig handledning under sin VFU som paradoxalt. Det är svårt att förklara denna paradoxalitet utifrån enkätundersökningen.

De studenter som angav att de inte fick den handledning de behövde under sin VFU fanns i fallande ordning inom:

- VVS och fastighetsprogrammet.

- Hantverksprogrammet.

- Fordons- och transportprogrammet.

- Bygg- och anläggningsprogrammet. 


\section{Efter avslutad yrkeslärarutbildning}

Av de 139 respondenter som svarar på frågan om de har en tjänst som yrkeslärare anger 113 att de har en lärartjänst, det vill saga att 81 \% av de tidigare lärarstudenterna arbetar som yrkeslärare efter utbildningen. Av de 26 respondenter (19 \%) som inte har en lärartjänst finns en betydande andel inom Hantverksprogrammet och Hotell- och turismprogrammet. 18 respondenter anger att de har annan anställning, 6 respondenter har inte sökt någon lärartjänst och 2 respondenter har sökt lärartjänst, men inte fått någon.

Högst andel yrkeslärare som svarar att de arbetar som yrkeslärare efter yrkeslärarutbildningen finns inom Restaurang- och livsmedelsprogrammet samt VVSoch fastighetsprogrammet. Lägst andel finns inom Hantverksprogrammet samt Hotell- och turismprogrammet.

98 av de 113 respondenter som har en lärartjänst (87 \%) svarar att de arbetar 76-100 \% som yrkeslärare och bland dem är Fordon- och transportprogrammet, El- och energiprogrammet, Bygg- och anläggningsprogrammet, Industritekniska programmet samt Vård- och omsorgsprogrammet främst representerade.

Frågan ställdes till de 113 respondenter som har en lärartjänst, om de undervisar enbart i de yrkesämnen som de har fått behörigheter för. Här finns 126 svar och skillnaden beror på att studenterna som har varit antagna till flera yrkesämnen inom ett eller flera program kan ange att de har undervisat enbart i yrkesämnen som de har fått behörighet för i ett program, men också undervisat i yrkesämnen de inte fått behörighet för inom andra program. Av dessa 126 svar visar 75 svar (60 \%) att respondenterna undervisade i de yrkesämnen i programmen som de hade fått behörigheter i som yrkeslärare, där i fallande ordning yrkesämnen inom nedanstående program är dominerande:

- Restaurang- och livsmedelsprogrammet.

- Hantverksprogrammet.

- Naturbruksprogrammet.

51 av de 126 svaren (40 \%) visar att respondenterna undervisade i ämnen i ett program som de inte har behörighet i. Yrkesämnen inom nedanstående program anges i fallande ordning efter flest yrkeslärare som undervisar i ämnen de inte har behörighet $\mathrm{i}$ :

- El- och energiprogrammet

- Industritekniska programmet.

- Hotell och turismprogrammet.

Som framgått visade 51 svar (40 \%) att respondenterna undervisade i ämnen som de inte hade behörighet i. En följdfråga till de svaren var: Vilka är skälen till att du undervisar inom andra yrkesämnesområden än de du har din behörighet i? Fem skäl 
kunde anges, en respondent kunde ange flera skäl och totalt fanns 72 skäl angivna i de 51 svaren. Det absolut viktigaste skälet (60 svar av 72) var att de bedömde att de hade tillräcklig yrkesämneskunskap för flera ämnen än deras behörigheter.

På frågan om de kombinerar lärartjänsten med annan tjänst eller eget företag, har 125 respondenter svarat och 94 av dem (75 \%) svarar nej på frågan. Yrkesämnen inom Naturbruksprogrammet, VVS- och fastighetsprogrammet, El- och energiprogrammet, Restaurang- och livsmedelsprogrammet samt Hantverksprogrammet har flest lärare som kombinerar lärartjänsten med annan tjänst eller eget företag.

Av de 113 respondenter som angett att de arbetar som yrkeslärare, svarar 99 av dem (88 \%) på frågan om deras möjligheter till kompetensutveckling de har fått för att kunna undervisa inom yrkesämnen de inte hade lärarbehörighet $i$. Svaren visar att 70 av de 99 respondenterna (71 \%) inte har fått möjlighet till sådan kompetensutveckling. 29 av 99 respondenter (29 \%) svarar således att de har fått möjlighet till kompetensutveckling för att kunna undervisa inom yrkesämnen de inte hade lärarbehörighet i. De yrkeslärare som inte har fått en sådan kompetensutvecklingsmöjlighet finns i fallande ordning inom:

- VVS- och fastighetsprogrammet.

- Industritekniska programmet.

- Hantverksprogrammet.

- Bygg- och anläggningsprogrammet.

- Handels- och administrationsprogrammet.

- Fordons- och transportprogrammet.

De yrkeslärare som har fått möjlighet till kompetensutveckling för att kunna undervisa inom yrkesämnen de inte hade lärarbehörighet i finns i fallande ordning inom:

- El- och energiprogrammet.

- Barn- och fritidsprogrammet.

- Restaurang- och livsmedelsprogrammet.

Även inom dessa program är det dock endast hälften eller färre än hälften av lärarna som haft möjlighet till sådan kompetensutveckling. 


\section{Diskussion och slutsatser}

Genom en enkätstudie riktad till tidigare yrkeslärarstudenter har vi undersökt deras upplevelse av yrkeslärarutbildningen gällande antagning, VFU i utbildningen samt läraranställning och möjligheter till kompetensutveckling som yrkeslärare. Under studiens gång har vi presenterat tentativa resultat av studien vid ett par tillfällen och tagit emot synpunkter och erfarenheter från åhörare som i viss utsträckning utgör referenser inom de aktuella temata vi har haft för avsikt att undersöka.

\section{Antagning till yrkeslärarutbildningen}

Kravet på kvalificerade och relevanta yrkeskunskaper utifrån arbetslivserfarenheter utgör grund för antagningen (UHR, 2017) och enkätstudien visar att de sökande till yrkeslärarutbildningen hade lång yrkeserfarenhet, hela 80 \% hade mer än 8 års yrkeserfarenhet när de sökte utbildningen och cirka $60 \%$ hade mer än 16 års yrkeserfarenhet. Det innebär att yrkeslärarstudenter har en hög genomsnittsålder. Nästan alla av våra respondenter (över 90 \%) har blivit antagna i samtliga sökta yrkesämnen, men det framkommer också att studenter upptäcker att de inte har sökt till yrkesämnen som de faktiskt skulle ha kunnat söka till utifrån sina arbetslivserfarenheter. $83 \%$ av respondenterna i enkäten menar att de har tillräcklig yrkesämneskunskap för flera ämnen än vad deras behörigheter täcker, men en breddning av behörighet till fler yrkesämnen kan sökas först efter genomförd yrkeslärarutbildning (Skolverket, 2019).

Att söka till yrkeslärarutbildningen framstår utifrån våra respondenter som en individuell process då cirka $80 \%$ av dem anger att de sökte utbildningen på egen hand. Här har vi mött erfarna studievägledare som ifrågasätter att siffran stämmer och menar att de i hög utsträckning ger de sökande stöd i ansökningsprocessen. Det kan bero på hur vi ställt frågan i enkäten, där vi frågar om information inför ansökan och inte om stöd under själva ansökningsprocessen. Svaren indikerar dock att något mer behöver göras angående stöd i ansökningsprocessen.

Vi har också mött studenter inom yrkeslärarutbildningen som uttrycker att det har varit tidskrävande och svårt att skaffa de intyg som kan verifiera tidigare yrkeserfarenheter. Det kräver att man tar kontakt med tidigare arbetsgivare sedan lång tid tillbaka och som kanske inte ens har sin verksamhet kvar. Johansson (2019) diskuterar kritiska aspekter av att valideringen sker skriftligt, vilket kan innebära att en del sökande inte har tillgång till ett språk som artikulerar deras yrkeskunnande och att en muntlig framställning kan vara mer ändamålsenlig. Även sättet att dela upp yrkeskunnandet i kompetens, kunskap och färdigheter kan bli svårt för den sökande att tolka (Panican, 2016). 


\section{VFU i utbildningen}

VFU (den verksamhetsförlagda utbildningen) som utgör en tredjedel av utbildningen är viktig för att studenterna ska ges möjlighet att undervisa och med stöd av handledning på VFU-skolan utveckla didaktisk kunskap inom sina yrkesämnen. Det är ett centralt utbildningsuppdrag som VFU-skolorna ges ansvar för då lärosätena har begränsade möjligheter att ge yrkesämnesdidaktisk utbildning i 211 yrkesämnen. Innehållet i VFU styrs genom lärandemål i särskilda VFU-kurser som följs upp, bedöms och betygssätts av lärosätets personal i samråd med handledaren (jfr Regeringens proposition, 2010). Den verksamhetsförlagda delen i yrkeslärarutbildningen har även en viktig funktion för att ge lärarstudenterna möjlighet att vara en del av en skolas verksamhet och att bli delaktiga i ett lärarlag (Andersén \& Asghari, 2016). En sådan delaktighet ger studenterna förståelse av undervisningens grundvalar och ger möjlighet att utveckla en läraridentitet (Hultman m.fl., 2012).

I studien har vi främst riktat intresset mot att få veta om yrkeslärarstudenterna fick möjlighet att utveckla yrkesämnesdidaktisk kunskap inom sin VFU. Enkätsvaren visar att $75 \%$ av yrkeslärarstudenterna, under sin VFU, enbart undervisade i de yrkesämnen de hade blivit antagna till. Dessutom hade cirka $80 \%$ av yrkeslärarstudenterna en handledare med yrkesämneskunskaper i de yrkesämnen som de var antagna till. En övervägande andel av yrkeslärarstudenterna gavs således möjligheter att utveckla yrkesämnesdidaktisk kompetens genom att undervisa inom VFU med handledning i sina yrkesämnen.

$\AA$ andra sidan visar enkätsvaren att $25 \%$ av yrkeslärarstudenterna inte enbart undervisade i de yrkesämnen de hade blivit antagna till under sin VFU och att cirka $20 \%$ av yrkeslärarstudenterna inte hade en handledare med yrkesämneskunskaper i de yrkesämnen som studenterna var antagna till. Dessa studenter riskerade att inte få möjlighet att utveckla sin yrkesämnesdidaktiska kompetens under VFU. Det innebär också att dessa yrkeslärarstudenter kan bli behöriga i yrkes-ämnen som de har bristande yrkesämnesdidaktisk kunskap inom.

En fråga som har diskuterats vid våra presentationer av studien, men också på våra respektive lärosäten, är att det behövs ytterligare möjligheter för studenter att få tillgång till relevant yrkesämnesdidaktisk handledning inom alla yrkesämnen. Enkätsvaren visar att 18 av de tidigare studenter som hade VFU i egen tjänst inte hade tillgång till handledning i de egna yrkesämnena. Frågan om att arbeta inom egen tjänst under utbildningen framstår i dessa fall som problematiskt för möjligheten att utveckla yrkesämnesdidaktiskt kunnande. Gustavsson, Loeb och Kvarnemo (2018) anger att drygt hälften av yrkeslärarstudenterna gör sin VFU i egen tjänst. Studenten kan vara den ende som undervisar i ett yrkesämne på skolan och därmed sakna möjlighet till yrkesämnesspecifik handledning. Att så kan vara fallet indikeras också i enkätsvaren, där hälften av dem som anger att de inte har haft handledare i det egna yrkesämnet också haft VFU i egen tjänst. 
Ett resultat som vi menar är viktigt att lyfta fram är att drygt hälften av studenterna angav att deras VFU-handledare hade en liten eller ingen betydelse alls för deras nuvarande skicklighet som yrkeslärare. Det innebär att även studenter som hade VFU-handledare inom sina yrkesämnen menade att de inte fick behövligt stöd från handledaren för att utveckla yrkesämnesdidaktisk kompetens.

Utifrån Skolverkets statistik för läsåret 2017/18 hade Hotell och turism 63,4 \%, El och energi 51,7 \%, Bygg och anläggning 50,4 \%, Industriteknik 48,5 \%, Fordon och transport $47 \%$, och VVS och fastighet 38,7 \% lärare med pedagogisk högskoleexamen (Skolverket, 2018). De respondenter (75 av 142 svar, eller 53 \%) som angav att deras VFU-handledare hade liten eller ingen betydelse, är flest bland Industriteknik, VVS och fastighet, Bygg och anläggning, El och energi, Hotell och turism samt Fordon och transport. Med utgångspunkt i Skolverket (2018) menar vi att en lägre andel av de verksamma lärarna inom flertalet av dessa program har en pedagogisk högskoleexamen, och frånvaro av pedagogisk utbildning kan tänkas påverka yrkeslärares kompetens som VFU-handledare

De respondenter (67 av 142 svar, eller 47 \%) som angav att deras handledare hade haft mycket stor eller ganska stor betydelse för deras nuvarande skicklighet som yrkeslärare fanns främst bland de som hade sin VFU inom yrkesämnen på Barn och fritid, Restaurang och livsmedel och Vård och omsorg. Dessa yrkesprogram har med utgångspunkt i Skolverket (2018) också en betydligt högre andel lärare med pedagogisk högskoleexamen (mellan 69 och 86 \%) än flertalet av de program där handledaren angavs ha liten betydelse. Vi menar alltså att det kan finnas en relation mellan studenternas värdering av handledningen under VFU och i vilken utsträckning lärare på programmen har lärarbehörighet (pedagogisk högskolekompetens).

\section{Efter avslutad yrkeslärarutbildning}

Arbetslösheten bland behöriga yrkeslärare är låg (Högskoleverket, 2009) och vår enkätundersökning visar också 113 av 139 tidigare lärarstudenter (81 \%) arbetar som yrkeslärare efter utbildningen. Av de 26 respondenter $(19 \%)$ som anger att de inte arbetar som yrkeslärare är 18 verksamma i andra yrken och enbart 2 respondenter anger att de sökte en lärartjänst, men inte fått någon. Enkätundersökningen visar också att det finns en särskilt stor brist på yrkeslärare inom vissa program, exempelvis El- och energiprogrammet och Industritekniska programmet. På grund av yrkeslärarbristen kan skolorna se en potential i att kunna använda lärare utöver deras yrkesämneskunskaper i undervisningen. I enkätstudien undersökte vi också i vilken grad yrkeslärarna kombinerade en lärartjänst med annan tjänst eller eget företag och fann att det var vanligast inom Hantverksprogrammet och Naturbruksprogrammet och ovanligast inom Vård- och omsorgsprogrammet. Det kan finnas ett samband till de olika yrkesbranscherna och möjligheter att kombinera lärartjänster med annan verksamhet. En annan förklaring kan vara att yrkeslärare som endast har fått behörighet $\mathrm{i}$ att undervisa i ett 
eller ett fåtal ämnen kan ha svårare att få en heltidstjänst, och kanske är i behov av att kombinera yrkeslärartjänsten med annat arbete.

Frågan om det ska vara möjligt att bli antagen till endast ett eller ett fåtal yrkesämnen i yrkeslärarutbildningen har diskuterats vid våra respektive lärosäten och även kommit upp vid våra presentationer av studien. Det kan vara svårt att hitta VFU-placeringar till studenter som antas till utbildningen inom ett eller få yrkesämnen enligt uppgift från våra respektive universitet. VFU-skolorna helst vill ta emot lärarstudenter med en bredare yrkesämneskompetens.

Lloyd och Payne (2012) framhåller att yrkeslärares kompetensutveckling har positiva effekter på lärares undervisning och elevers lärande. Bland de positiva effekterna nämns upprätthållandet av en kvalitativ lärandemiljö där undervisningen kan anpassas till arbetsmarknadens kompetensbehov. Enligt Andersson och Köpsén (2018) kan yrkeslärarnas heltidsanställning begränsa möjligheterna till fortlöpande kompetensutveckling. En kombination av eget yrkesutövande med arbete som yrkeslärare kan därför ses som en möjlighet till kontinuerlig kompetensutveckling inom yrkesområdet.

Yrkesutbildningar står inför många utmaningar. Bland utmaningarna kan den kontinuerliga teknikutvecklingen och arbetsmarknadens efterfrågan på aktuell kompetens hos yrkesutövare nämnas (Misra, 2011). Skolorna behöver bli bättre på att skapa förutsättningar för sina yrkeslärare till kompetensutveckling, inte minst för att de ska kunna utbilda kompetenta yrkesutövare för den högteknologiska arbetsmarknaden. Möjlighet till kompetensutveckling för att bredda sin yrkesämnesbehörighet kan bli avgörande både för yrkeslärares anställningsform och för att säkra en god yrkesämneskunskap för undervisningen. Genom kompetensutveckling kan yrkeslärare bredda sin behörighet till flera yrkesämnen samt få bättre möjligheter att hålla sig uppdaterade inom sina yrkesämnen. 71 \% av yrkeslärarna i vår enkätundersökning svarade att de inte hade fått några möjligheter till kompetensutveckling för att kunna undervisa inom yrkesämnen de inte fick sin behörighet inom i anslutning till yrkeslärarutbildningen. En fråga som därför skulle vara intressant att undersöka vidare är hur de 29 \% av respondenterna som svarat att de fått tillgång till kompetensutveckling har kunnat kombinera det med sina lärartjänster.

Vår studie visar att det behövs stöd i ansökningsprocessen. Det finns en risk att potentiella yrkeslärarstudenter inte orkar ta tag i ansökningsprocessen. Vi menar att resultatet av vår enkät indikerar att information om möjligheter att söka till yrkeslärarutbildning inte når ut till potentiella sökanden och att stödet $\mathrm{i}$ ansökningsprocessen bör förbättras.

\section{Slutsatser}

Vi vill framhålla att vi utifrån vår studie kan dra slutsatsen att vi behöver veta mer om konsekvenserna för yrkeslärare och yrkeslärarutbildningen av lärarut- 
bildningsreformen 2011. Resultatet från vår enkätstudie kan endast ge indikationer som i sin tur kan ge stöd både för en breddning och för en fördjupning $i$ kommande studier.

Aktuell statistik visar att bristen på yrkeslärare med lärarexamen är fortsatt hög trots reformens intentioner att minska andelen obehöriga yrkeslärare. Genom förkortningen av yrkeslärarutbildningen försvåras yrkeslärares möjligheter till fortsatta akademiska studier efter yrkeslärarutbildningen, som nu framstår som en återvändsgränd i det akademiska utbildningssystemet. Det berättigar frågan om vilka som kommer att bli framtida forskare inom det yrkesdidaktiska området? Vilka vägar skapas vid lärosätena för att ge vägar framåt i utbildningssystemet för yrkeslärarna, med det stora behov som finns av mer kunskap inom området?

\section{Slutnoter}

${ }^{1}$ De andra tre examina är förskollärarexamen, grundlärarexamen och ämneslärarexamen (Regeringens proposition, 2010).

\section{Om författarna}

Hamid Asghari är universitetslektor vid institutionen för pedagogiskt arbete vid Karlstads universitet. Hans forskningsintresse är yrkesutbildning med ett särskilt fokus på yrkesundervisning och yrkeslärande. Asghari är verksam inom yrkeslärarutbildningen där han undervisar yrkeslärarstudenter och handleder dem i deras utvecklingsarbeten.

Ingrid Berglund är universitetslektor vid institutionen för pedagogik och specialpedagogik vid Göteborgs universitet. Hennes forskningsintresse finns inom området yrkesdidaktik och utveckling av yrkeskunnande inom olika yrkesområden, såväl skolförlagt som arbetsplatsförlagt. Ingrid är huvudsakligen verksam inom yrkeslärarutbildningen vid Göteborgs universitet. 
Hamid Asghari \& Ingrid Berglund

\section{Referenser}

All, K.L., Pettersson, J. \& Teräs, M. (2018). Uppgifter som medierande artefakter inom yrkeslärarutbildningen. Nordic Journal of Vocational Education and Training, 8(3), 78-97.

Andersén, A. \& Asghari, H. (2016). Identitetsframträdande och positionering i handledares berättelser. Kapet: Karlstads universitets Pedagogiska Tidskrift, 12(2), 87-102.

Andersén, A., Asghari, H. \& Petersson, M. (2018). Yrkesämnesdidaktik på universitet: Mål, innehåll, arbetssätt och examination. Nordic Journal of Vocational Education and Training, 8(3), 98-123.

Andersson, P. \& Fejes, A. (2014). Svensk forskning om validering av vuxnas lärande: Trender och tendenser. Pedagogisk forskning i Sverige, 19(4-5), 324-344.

Andersson, P. \& Köpsén, S. (2014). Yrkesdidaktiska utmaningar. I S. Köpsén (Red.), Lära till yrkeslärare (s. 217-224). Lund: Studentlitteratur.

Andersson, P. \& Köpsén, S. (2018). Maintaining competence in the initial occupation: Activities among vocational teachers. Vocations and Learning, 11(2), 317-344.

Annerberg, A. \& Fändrik, A.K. (2019). Att vetenskapligt förankra ett yrkeslärarprogram: Erfarenheter från ett utvecklingsprojekt. Nordic Journal of Vocational Education and Training, 8(3), 124-140.

Berglund, I. (2009). Byggarbetsplatsen som skola - eller skolan som byggarbetsplats? En studie av byggnadsarbetares yrkesutbildning. Doktorsavhandling. Stockholm: Institutionen för didaktik och pedagogiskt arbete, Stockholms universitet.

Berglund, I., Höjlund, G., Kristmansson, P. \& Paul, E. (2017). Gymnasial lärlingsutbildning ur ett pedagogiskt och didaktiskt perspektiv - med utgångspunkt $i$ försöksverksamheten 2008-2014. Göteborg: Göteborgs universitet.

Brennan Kemmis, R. \& Green, A. (2013). Vocational education and training teachers' conceptions of their pedagogy. International Journal of Training Research, 11(2), 101-121.

Du Plessis, E.C., Marais, P., Van Schalkwyk, A. \& Weeks, F. (2010). Adapt or die: The views of Unisa student teachers on teaching practice at schools. Africa Education Review, 7(2), 323-341.

Fenton-O'Creevy, M., Brigham, L., Jones, S. \& Smith, A. (2015). Students at the academic workplace boundary. I E. Wenger-Trayner, M. Fenton-O'Creevy, S. Hutchinson, C. Kubiak \& B. Wenger-Trayner (Red.), Learning in landscapes of practice: Boundaries, identity, and knowledgeability in practice-based learning (s. 4363). Abingdon: Routledge.

Gustavsson, S., Loeb, I.H. \& Kvarnemo, C. (2018). Lärande för hållbar utveckling i yrkeslärarutbildning. Nordic Journal of Vocational Education and Training, 8(3), 19-35. 
Hattie, J. \& Timperley, H. (2007). The power of feedback. Review of Educational Research, 77(1), 81-112.

Hedman, A. (2001). I nationens och det praktiska livets tjänst: Det svenska yrkesskolesystemets tillkomst och utveckling 1918 till 1940. Doktorsavhandling. Umeå: Pedagogiska institutionen, Umeå universitet.

Hultman, G., Wedin, A-S. \& Schoultz, J. (2012). Lärandet och hur det synliggörs under lärarutbildningens praktikperioder: Handledning och överföring av yrkeskunnande. Didaktisk tidskrift, 22(2), 335-358.

Håkansson, A. (2017). Att synliggöra studenters yrkeskunnande i den verksamhetsförlagda delen av yrkeslärarutbildningen. Högskolepedagogisk debatt, 2, 35-44.

Högskoleverket. (2009). Högskoleutbildningarna och arbetsmarknaden: Ett planeringsunderlag inför läsåret 2009/10 (rapport 2009:5 r). Hämtad 27 mars,

2018, från

https://studentportal.gu.se/digitalAssets/1277/1277438_planeringsunderla g0905R.pdf

Högskoleverket. (2011a). Högskoleutbildningarna och arbetsmarknaden: Ett planeringsunderlag inför läsåret 2010/11 (rapport 2010:1). Hämtad 15 november, 2018, från https://studentportal.gu.se/digitalAssets/1353/1353626_1001rhogskoleutbildningarna-arbetsmarknad.pdf

Högskoleverket. (2011b). National Qualifications Framework. Hämtad 11 november, 2019, från

https://www.uhr.se/globalassets/_uhr.se/internationellt/nqf/12-5202-10national-qualifications-framework.pdf

Isacsson, A., Stigmar, M. \& Amhag, L. (2018). The content, challenges and values that form Nordic vocational teacher education. Ammattikasvatuksen aikakauskirja, 20(2), 38-50.

Johansson, M.C. (2019). The institutionalisation of validation and the transformation of vocational knowledge: The case of admission into vocational teacher education in Sweden. Doktorsavhandling. Växjö: Linnaeus University Press.

Köpsén, S. (2014). Yrkeslärares dubbla yrkesidentiteter. I S. Köpsén (Red.), Lära till yrkeslärare: En introduktion (s. 19-35). Lund: Studentlitteratur.

Lloyd, C. \& Payne, J. (2012). Raising the quality of vocational teachers: Continuing professional development in England, wales and Norway. Research Papers in Education, 27(1), 1-18.

Misra, P.K. (2011). VET teachers in Europe: Policies, practices and challenges. Journal of Vocational Education \& Training, 63(1), 27-45.

Panican, A. (2016). Valideringens Janusansikte: Branschorganisationernas förhållningssätt till validering, SeQF och generiska kompetenser. Rapport nr 22. Stockholm: Ratio.

Regeringens proposition. (2010). Bäst i klassen - en ny lärarutbildning (2009/10:89). Hämtad 15 november, 2018, från 
https://www.regeringen.se/contentassets/c0d91cff5e4d4223b15334ce441cd 00a/bast-i-klassen---en-ny-lararutbildning-prop.-20091089

Regeringskansliet. (2014). En nationell referensram för kvalifikationer för livslångt lärande. Stockholm: Utbildningsdepartementet.

Saco. (2019). Framtidsutsikter: Här finns jobben för akademiker år 2023. Hämtad 11 november, 2011, från https://www.saco.se/opinion/rapporter/framtidsutsikter/

Samuelsson, M. \& Johansson, E.M. (2018). Strategiskt och operativt arbete med validering av reell kompetens: Ett följeforskningsprojekt vid Högskolan Väst. Trollhättan: Institution för Individ och Samhälle, Högskolan Väst.

Skolverket. (2018). Samlad redovisning och analys inom yrkesutbildningsområdet. Hämtad 11 november, 2019, från https:// www.skolverket.se/publikationsserier/rapporter/2018/samladredovisning-och-analys-inom-yrkesutbildningsomradet-2018

Skolverket (2019). Ansök om att utöka legitimation med fler behörigheter. Hämtad 6 mars, 2019, från https://www.skolverket.se/regler-och-ansvar/larar--ochforskollararlegitimation/utoka-larar--och-forskollararlegitimation-med-flerbehorigheter/ansok-om-att-utoka-larar--och-forskollararlegitimation-medfler-behorigheter

SOU 1994:101. Höj ribban! Lärarkompetens för yrkesutbildning: Slutbetänkande av utredningen om kompetenskrav för gymnasielärare $i$ yrkesämnen. Stockholm: Utbildningsdepartementet.

SOU 2008:12. Finansiella sektorn bär frukt: Analys av den finansiella sektorn - ur ett svenskt perspektiv. Stockholm: Statens offentliga utredningar.

SOU 2008:112. Yrkeskunnande: En likvärdig sökväg till lärarutbildningen mot yrkesämnen. Stockholm: Statens offentliga utredningar.

Thång, P-O. (2013). Yrkespedagogisk forskning i vardande? I I. Wernersson \& I. Gerrbo (Red.), Differentieringens janusansikte: En antologi från institutionen för pedagogik och specialpedagogik vid Göteborgs universitet (s. 223-256). Göteborg: Acta Universitatis Gothoburgensis.

Trost, J. (2012). Enkätboken. Lund: Studentlitteratur.

UHR. (2017). Särskilda behörighetskrav för yrkeslärare. Hämtad 7 oktober, 2017, från https://www.uhr.se/studier-och-antagning/tilltrade-tillhogskolan/Behorighet-till-grundniva/Sarskilda-behorighetskrav-forlararutbildningen/

UHRFS (2013:4). Universitets- och högskolerådets föreskrifter om kvalificerade och relevanta yrkeskunskaper för särskild behörighet till utbildning som leder till yrkeslärarexamen. Hämtad 3 mars, 2018, från https://www.uhr.se/globalassets/_uhr.se/publikationer/lagar-ochregler2/uhrfs/2013/uhrfs-2013-4.pdf 
UHRFS. (2017:3). Föreskrifter om ändring i universitets- och högskolerådets föreskrifter (UHRFS 2013:4) om kvalificerade och relevanta yrkeskunskaper för särskild behörighet till utbildning som leder till yrkeslärarexamen. Hämtad 22 maj, 2019, från https://www.uhr.se/globalassets/_uhr.se/publikationer/lagaroch-regler2/uhrfs/2017/uhrfs-2017-3-webb.pdf

UHRFS. (2018:3). Föreskrifter om ändring i universitets- och högskolerådets föreskrifter (UHRFS 2013:4) om kvalificerade och relevanta yrkeskunskaper för särskild behörighet till utbildning som leder till yrkeslärarexamen. Hämtad 22 maj, 2019, från https://www.uhr.se/globalassets/_uhr.se/publikationer/lagar-ochregler2/uhrfs/2018/uhrfs-2018-3.pdf 